stellar medium) can then only be explained if most of the high-energy electrons responsible for the emission originate within the supernova, as proposed by van der Laan for the early stages of the expansion.

There appear to be a total of some 10-12 localized regions distributed around the shell which have an even greater volume emissivity; these sources, which have typical dimensions of $0 \cdot 2-0.3$ parsec, might be associated with regions of greater magnetic field strength.
We thank the Director of the University Mathematical Laboratory for the use of Edsac II.

1 Ryle, M., Nature, 194, 517 (1962).

2 Lequeux, J., Ann. d'Astrophys, 25, 221 (1962).

${ }^{3}$ Maltby, P., and Moffet, A. T., Astrophys. J., Supp., 7, 141 (1962).

- Moffet, A. T., Science, 146, 764 (1964).

- Ryle, M., and Neville, A. C., Mon. Not. Roy. Astro. Soc., 125, 39 (1962).

6 Minkowski, R., IAU/URSI Symp. Radio Astronomy, Paris, 315 (1958).

7 Laan, H. van der, Mon. Not. Roy. Astro. Soc., 124, 125 (1962).

${ }^{8}$ Laan, H. van der, Mon. Not. Roy. Astro. Soc., 124, 179 (1962).

\title{
OBITUARIES
}

\section{Prof. J. M. F. Drummond}

WrTH the death of James Montagu Frank Drummond, emeritus professor of botany in the University of Manchester, at his home in Exmouth at the age of eighty-three, British botany has lost an unusually well informed academic and practical exponent. He was born in 1881, the second son of J. R. Drummond of the Indian Civil Service. $\mathrm{He}$ is survived by his second wife, née Dorothy Maria Farrant. His first wife, née Agnes Marguerite Ives, died in 1923.

Drummond was educated at King's College, London, and at Gonville and Caius, Cambridge, where he had the distinction of holding the Frank Smart research studentship during 1904-6. His first appointment as lecturer in botany at Armstrong College, Newcastle upon Tyne (1906), was followed, in 1909 , by his joining the staff of Prof. F. O. Bower in the University of Glasgow as lecturer in plant physiology. There he remained until 1921, his teaching on various branches of botany being much appreciated by his students. It was during this period that he produced his masterly translation and up-to-date annotation of an eminent - and extensive-German text, Dr. G. Haberlandt's Physiologische Pflanzenanatomie (Physiological Plant Anatomy), 1914. His academic work was interrupted by the First World War when he saw active service with the Highland Light Infantry in France and the Palestine campaign.

When, in 1921, the Scottish Plant Breeding Station was established at Corstorphine, Midlothian, Drummond was invited to become its first director. His botanical interests, always broadly based and liberal, now turned in the direction of geneties, with special emphasis on the improvement of cultivated plants. Under his care the new Station was staffed and organized and was soon known for its varied and progressive activities. His work in this new field is recorded in the annual reports of the Station and in various public addresses. But still further opportunities were to eome his way. In 1925, he was appointed Regius professor of botany in the University of Glasgow, and in 1930 he became George Harrison professor of botany in the University of Manchester, a post which he held until his retirement in 1946. During this period the trustees of the former Manchester Royal Botanical Society made a considerable bequest to the University to promote interest in horticulture in the region. On the funds thus made available, Prof. Drummond purchased and developed in Cheshire what are now the Jodrell Bank Botanical Experimental Grounds, and he also established a University lectureship in horticulture and a system of training for student gardeners. All this was very close to his heart: he was a true lover of plants and gardens and possessed an unrivalled knowledge of species, both native and exotic.

Much of the effect of Prof. Drummond's work lay, not so much in what he achieved under his own name, but rather in what he did for others and enabled them to achieve. For example, he greatly assisted Prof. Bower in re-editing, and in incorporating new material in, the third edition of Botany of the Living Plant. To all, but especially to his younger colleagues and students, he was unstinting of his help and encouragement of their work. His outlook, thinking and writing were of unusual clarity and perspicacity. He held firmly to the view that a university was not simply a seat of learning but essentially a place both for study and character formation. This led him, among many other activities, to continue his interest in military training, and from 1932 until 1945 he was officer-incommand of the University Officers' (Senior) Training Corps. During the Second World War this greatly enlarged unit, which he organized and commanded with distinction, functioned as the 61st (Lancs.) Battalion of the Home Guard.

C. W. WARDLAW

\section{Mrs. Dorothea Waley Singer}

Mrs. Dorothea Singer, the widow of Prof. Charles Singer, the historian of medicine and science, died on June 24, 1964. She was well known in many countries, especially for her work on early manuscripts dealing with science and medicine, and for her activities on various international bodies.

Dorothea Waley Singer, the eldest daughter of Nathaniel L. Cohen, and of Julia M. Waley, was born in London on December 17,1882 . In early womanhood she spent some years at Queen's College, London, and in 1910 she married Charles Singer, who was then engaged mainly in clinical and pathological work. Soon afterwards they both became interested in the history of medicine and science, and in 1913 they presented a joint communication on the history of the contagium vivum at the International Medical Congress held in London in that year. In following years they wrote several joint papers, dealing mainly with. medieval medicine.

Meanwhile, Mrs. Singer had been very actively engaged on studying the surviving medieval manuscripts in the British Isles which dealt with different aspects of science and medicine. In 1916 she presented before the History Section of the Royal Society of Medicine a very careful and detailed study of more than a hundred plague tractates of the fourteenth and fifteenth centuries. She had for some years been trying to catalogue and codify the manuscripts in Britain which bore in any way on science and medicine, and by 1919 she knew of more than 30,000 , many of which were, of course, direct copies or variants. The full fruition of these investigations began to be seen in 1924, when the Union Académique International published the first volume of her monumental catalogue of alchemical manuseripts in the British Isles. The first volume is a small work because it deals only with the comparatively few Greek manuscripts in Britain. But the three succeeding volumes (1928-31) deal with the vast number of Latin and vernacular manuscripts, and they form a catalogue of great complexity and scholarship which will remain a standard work.

Mrs. Singer had continued to work on plague tractates, and in 1950 she published a definitive catalogue of Latin and vernacular works on plague which dated from before the sixteenth century and were extant in Great Britain. Her cumulative catalogue, dealing with all scientific subjects, forms a very large collection of cards, and microfilms of it are deposited in some of the great libraries of the world. 
Apart from this work on manuscripts Mrs. Singer wrote several books and many papers in learned journals. In 1924 she published a very useful study of Ambroise Paré, together with a generous selection from his writings. Her important long paper on Sir John Pringle and his times gives much information which is not readily available elsewhere. For nearly twenty years she was intermit. tently engaged on a detailed examination of the works of Giordano Bruno, and in 1950 her Giordano Bruno, his Life and Thought was published. It is a very scholarly and illuminating investigation of the work of that complex personality. Her last book to be published was a translation from the German of Prof. Klemm's History of Technology (1959).

Mrs. Singer was also well known for her activities in various societies, British and international, and for her great interest in social work. She performed an important service in the placing of girl refugees from Nazi Germany as student nurses in British hospitals, and for many years she did much to stimulate the improvement of hearingaids for the deaf. Along with her husband she for many years provided generous hospitality to numerous foreign scientists and scholars visiting Britain.

E. AsHWORTH UNDERWOOD

\section{Dr. I. J. Kř́iženecký}

DR. I. JAROsLAV KřížENECKÝ, director of the Gregor Mendel Museum in Brno, died on December 21, 1964, at the age of sixty-eight. He was born and educated in Prague. Between the two World Wars his researches into animal breeding took him to the United States and to England. In 1921 he moved to Brno, where he was professor of animal breeding and genetics in the College of Agriculture until 1949. In the 1950's he won the admiration and friendship of many biologists both in Czechoslovakia and in other countries for his resolute defence of Mendelian genetics. When plans for a Mendel Museum were made in 1962, Dr. Křiženecký was chosen to direct the work. It is largely due to his untiring efforts that a Department of Genetics has been founded in the Moravian Museum and a Memorial Hall is being prepared for the forthcoming Mendel symposium this summer. Dr. Křiženecký worked very hard despite great and protracted suffering to make this symposium a worthy tribute to Mendel. It is sad that he has not lived to complete his work. Czechoslovak scientists have lost a dedicated scientist who, like Mendel, was a humble man and a great teacher.

R. C. Olby

\section{NEW FELLOWS OF THE ROYAL SOCIETY}

$\mathrm{A}^{\mathrm{T}}$ T a meeting of the Royal Society on March 18, the following were elected to fellowship of the Society:

DR. G. D. H. BeLL, director, Plant Breeding Institute, Cambridge, distinguished for his application of genetical science to the advancement of plant breeding.

Prof. R. E. BeLL, Rutherford professor and director of the Foster Radiation Laboratory in McGill University, Montreal, Canada, distinguished for his contributions to nuclear physics, especially for his measurements of very short life-times and of the binding energy of the deuteron.

Dr. S. Brenner, member of the Scientific Staff of the Medical Research Council Laboratory of Molecular Biology, University Postgraduate Medical School, Cambridge, distinguished for his contributions to molecular biology, especially in the study of the genetic material and its control of protein synthesis.

DR. G. S. BRtndley, lecturer in physiology at the Department of Physiology, in the University of Cambridge, distinguished as a physiologist, especially for his contributions to the study of human colour vision.

Prof. B. N. Brockhouse, professor of physics in McMaster University, Hamilton, Canada, distinguished for his pioneering work on slow neutron spectroscopy, and for the applications of this tochnique to lattice dynamics and spin-waves.

Prof. A. R. Coltar, Sir George White professor of aeronautical engineering in the University of Bristol, distinguished for his contributions to aero-elastic theory, the engineering application of matrices, aerodynamies, and for his work on aircraft flutter and stability.

Sir Edward Collingwood, mathematician, Alnwick, Northumberland, distinguished for his contributions to the theory of functions, and in particular for his work on cluster sets of arbitrary functions.

DR. R. R. A. Coombs, assistant director at the Department of Pathology in the University of Cambridge, distinguished for his contributions to the immunological study of cell surfaces, of conglutinins and immunoconglutinins, and of allergic phenomena.

Prof. K. G. Denbigh, Courtaulds professor of chemical engineering and director of the Chemical Engineering Laboratories at the Imperial College of Science and Tech- nology, in the University of London, distinguished for his application of chemical thermodynamics and kinetics to the optimization and improvement of chemical reaction processes.

Prof. G. E. FoGG, professor of botany at Westfield College, in the University of London, distinguished for his work on the metabolism of the algae and especially on nitrogen fixation in the blue-green algae.

DR. C. E. Ford, head of the Cytogenetics Section, Medical Research Council Radiobiological Research Unit, Harwell, distinguished for his contributions to the cytogenetics of mammals, and for his studies of chromosomal abnormalities in man.

Prof. R. A. Gregory, George Holt professor of physiology in the University of Liverpool, distinguished for his work on the mechanism of gastro-intestinal movement and gastric secretion.

Prof. Dorothy HiLl, research professor of geology in the University of Queensland, Brisbane, Australia, distinguished for her researches on Palaeozoic fossil corals, their stratigraphical implications and the geological significance of their distribution on a world scale.

Prof. A. W. Johnson, Sir Jesse Boot professor of organic chemistry and head of the Department of Chemistry in the University of Nottingham, distinguished for his work on the organic chemistry of natural products, especially that of vitamin $\mathrm{B}_{12}$.

Prof. R. V. Jones, professor of natural philosophy in the University of Aberdeen, distinguished for fundamental physical measurements by novel instruments of exceptional precision; and for application of scientific methods to defence.

Prof. C. Kemball, professor of physical chemistry in Queen's University of Belfast, distinguished for his application of modern physico-chemical methods to the study of adsorption and catalysis at metal surfaces.

DR. J. S. KENNEDY, senior principal scientific officer, Agricultural Research Council Unit of Insect Physiology, Department of Zoology, Cambridge, distinguished for his contributions to the problem of insect migration and for his studies of the physiology and behaviour of locusts and greenfly. 